BIOMEDICAL AND BIOSOCIAL ANTHROPOLOGY
Official Journal of the International Academy
of Integrative Anthropology
journal homepage: http://bba-journal.com

\title{
Galectin-3 - a modern biomarker for the diagnosis of left ventricular hypertrophy and chronic heart failure and control of treatment of patients with hypertension
}

Ruzhanska V. O., Sivak V. G., Polishchuk T. V., Zhebel V. M.

National Pirogov Memorial Medical University, Vinnytsya, Ukraine

\section{ARTICLE INFO}

Received: 6 September, 2018

Accepted: 30 October, 2018

UDC: $616.12-$

$008.331 .1+616.124+616.12-$ $008.46+612.398+616-071+616-$ $037+616-08$

\section{CORRESPONDING AUTHOR}

e-mail: ruganskaya@gmail.com Ruzhanskaya V. O.
The development of new methods for the prevention and treatment of chronic heart failure and its control is an urgent medical and social problem. In this regard, using of new biological markers of the disease may be useful for early diagnosis of the disease, predict a clinical course, monitor the effects of pharmacotherapy (personalized medicine) and play an important role in stratifying the patient's risk. In 2013, according to the recommendation of the American Heart Association, a galectin-3 was introduced into the pool of such biomarkers for prevention and treatment of chronic heart failure. Objective: to improve prediction of the course and effectiveness of the therapy for hypertension and chronic heart failure as the hypertension complication in men 40-60 years old by applying the level of galectin-3 as a biomarker. There were observed the men 40-60 years old with hypertension and chronic heart failure for the concentration of galectin-3. Also, there were observed subjects without cardiovascular pathology ( $n=79$ ), the men with hypertonic disease with myocardial hypertension $(n=62)$ and the men with chronic heart failure II-III functional class of NYHA $(n=50)$ for the indicators of central and systemic hemodynamics. The level of galectin-3 was determined by immunoassay analysis on the equipment "Stat Fact 300". Structural and functional parameters of myocardium were assessed by an ultrasound method using the equipment "RADMIR ULTIMARA". Data statistical analysis was performed on a personal computer using standard statistical package "Statistica 10.0". All data is presented in the form of average $(M)$ and standard deviation $( \pm \sigma)$. It has been established that the concentration of galectin-3 significantly decreases against the background of treatment. The level of galectin-3 in the patients with the II stage of hypertonic disease with good treatment effect was close to normal values compared to those with moderate treatment effect. In terms of patients with hypertension III stage, the level of galectin-3 also decreased, indicating the possibility of therapy monitoring using this biomarker. The mathematical model of the galectin-3 influencing factors also has been determined in patients with hypertension. The boundary level of the galectin-3 has been calculated, it is counted $46,51 \mathrm{pg} / \mathrm{ml}$. It might be assumed a moderate effect of the treatment of hypertensive patients and chronic heart failure in males.

Keywords: hypertonic disease, left ventricular hypertrophy, chronic heart failure, galectin-3.

\section{Introduction}

Despite significant progress in the perception, diagnosis and treatment of hypertension, blood pressure monitoring is inadequate in at least half of hypertensive patients [27]. Accordingly, the risks of coronary heart disease, myocardial infarction, cerebral stroke, chronic heart failure (CHF), atrial fibrillation, renal failure and other complications remain uncontrolled. The prevalence of hypertension (HD) in the world is projected to rise to 1.5 billion people by 2025 , leading to 7.6 million premature deaths (about $13.5 \%$ of the total), $54 \%$ of strokes and $47 \%$ of events caused by ischemic heart disease [21].

With an increase in the systolic blood pressure of 20 $\mathrm{mmHg}$, and diastolic - at $10 \mathrm{mmHg}$ the risk of developing cardiovascular disease is doubled [4]. However, today about 
$9 \%$ of patients with arterial hypertension do not know about their high blood pressure [25].

At rates of growth of morbidity CHF ranks first among all cardiovascular pathology. According to national registries of European countries, the prevalence of this syndrome is 1$9 \%$, its frequency increases with age and after age 65 reaches $10-28 \%$. Probability of death in CHF for a year from the moment of the first clinical symptoms is $10-15 \%$ - among all patients, and for 5 years - 50\%. In severe cardiac decompensation, each second dies for a year. Over the past decade, mortality from this pathology has increased 2-fold. In developed countries, the main causes of $\mathrm{CHF}$ are HD and ischemic heart disease $[15,16]$. That is why the success in timely diagnosis, prevention and treatment of HD and $\mathrm{CHF}$ in its background, is inextricably linked with the results of studying the mechanisms of their occurrence and progression [20].

The key component of the development of CHF in HD is left ventricular hypertrophy and concomitant recent myocardial fibrosis, which compromises the function of the heart. Fibrosis initially manifests diastolic dysfunction, with progression of the disease, systolic dysfunction occurs [28].

As a biomarker, a state of connective tissue and, in particular, myocardial fibrosis, has been proposed for galectin-3, which belongs to the family of galectin proteins [5]. It was found that the concentration of galectin-3 in the blood is maximal at the peak of myocardial fibrosis and inflammation that arises as a result of heart failure [2, 14]. It is believed that galectin-3 reflects central processes mediating nonadaptive cardiac remodeling [7]. Several studies have shown that galectin-3 markers of increased mortality and left ventricular remodeling in patients with and without CHF of different etiology [3, 26, 30]. According to Kubanek M. et al. [17] galectin-3 plays an important role in the initial stages of heart failure formation and is an important predictor of left ventricular hypertrophy. One of the certain limitations in estimating the prognostic value of galectin-3 is the dependence on sexual and age-related differences, as well as on the size of renal glomerular filtration [19].

Objective: to improve prediction of the course and effectiveness of therapy for hypertension and chronic heart failure, which is its complication in men $40-60$ years by applying the level of galectin-3 as a biomarker.

\section{Materials and methods}

The study was performed according to the standards of proper clinical practice and the principles of the Helsinki Declaration. A written informed consent was received before enrollment of participants in the study.

The following males - residents of Podillya region were studied: 79 men aged 40-60, average age $57.06 \pm 0.50$ years, with no signs of cardiovascular disease, 62 men, average age $49.19 \pm 0.66$ years, with stage II hypertensive disease and 50 men, average age $50.14 \pm 0.99$ years, with HD complicated by CHF. During enrollment of males in the groups of patients with stage II HD and HD complicated by
$\mathrm{CHF}$, the following factors were considered: verified diagnosis of $\mathrm{HD}$ (with obligatory exclusion of symptomatic hypertension), the presence of LVH, confirmed by clinical and instrumental examinations. Exclusion criteria were symptomatic arterial hypertension, impaired renal function and liver, coronary heart disease developed prior to HD, endocrine, hematological, neoplastic and autoimmune disorders, complications of HD - myocardial infarction, acute cerebrovascular accident. In study patients with HD, the diagnosis of concomitant coronary artery disease was excluded after assessment of pre-test probability of the disease on the basis of simple clinical indicators complaints, anamnesis of the disease, detailed data analysis of outpatient cards of patients, results of ECG at rest and ultrasound examination of the heart at rest [10].

All the males were inpatients at Vinnytsia Regional Specialized Clinical Hospital of Radiation Protection of Ministry of Health of Ukraine and Military Medical Clinical Center of Central Region of Air Forces of Ukraine, and were also observed on outpatient basis from December 2013 to July 2014.

Plasma galectin-3 concentration of study patients was determined by enzyme-linked immunoassay using standard set of reagents produced by Bender MedSystems $\mathrm{GmbH}$ (Austria), and "Stat Fact 330" apparatus. Detection of galectin3 level is indicated in attestation certificate of the laboratory. Reference value of plasma galectin-3 concentration - 0.0 $2.28 \mathrm{ng} / \mathrm{ml}$, average level - $0.54 \mathrm{ng} / \mathrm{ml}$.

Blood sampling was done in fasting state from cubital vein in the amount of $2 \mathrm{ml}$ whole blood at 8 a.m. Then $0.5 \mathrm{ml}$ of plasma was separated, time between sampling of whole blood and plasma separation was less than $30 \mathrm{~min}$. The separated plasma was frozen at $-25^{\circ} \mathrm{C}$.

Electrocardiogram registration was done according to conventional method using 12 standard leads. Blood pressure was measured according to recommendations of WHO experts. Evaluation of parameters of systemic and intracardiac hemodynamics was performed using echocardiography on echogram "RADMIR ULTIMARA" (Kharkiv, Ukraine). Left ventricular muscle mass index (LVMMI) was calculated using Penn Convention formula. $\mathrm{LVMMI} \geq 115 \mathrm{~g} / \mathrm{m}^{2}$ was considered the criterion of $\mathrm{LVH}$ for males according to clinical recommendations of the European Society of Hypertension (ESH) and the European Society of Cardiology (ESC) to treatment of arterial hypertension $(2013,2016)[9,22]$.

Moderate hypertrophy of the left ventricle was established at the value of the index of left ventricular myocardial mass to $170 \mathrm{~g} / \mathrm{m}^{2}$, expressed above $170 \mathrm{~g} / \mathrm{m}^{2}$. The calculation of the relative thickness of the walls of the left ventricle by the formula [ $2 \mathrm{x}$ end-systolic thickness of the left wall of the left ventricle) / end diastolic size of the left ventricle], makes it possible to distinguish between the increase in left ventricular mass on concentric (relative thickness of the walls of the left ventricle $\geq 0.42$ ) and eccentric (relative thickness walls of the left ventricle $\leq 0.42$ ), and also allows for the concentric 
remodeling of the left ventricle (normal mass of the left ventricular myocardium with an increase in the relative thickness of the walls of the left ventricle $\geq 0.42$ ) [23]. In the pulsed Doppler regime, the transdermal flow parameters were studied: the maximum speed of rapid early diastolic filling $(E)$ and the maximum rate $(A)$ of left ventricular filling during left systole $(\mathrm{cm} / \mathrm{s})$, their ratio $(E / A)$. Diastolic function of the left ventricle was evaluated in accordance with the current recommendations [12]. The state of the systolic function of the left ventricle myocardium was estimated by the indicator of the ejection fraction. The systolic function was considered to be preserved when the fraction rate exceeded $40 \%$. In determining the boundary level of the galectin-3 in blood plasma, the formula proposed by Antonomov M.Yu. and others.[1, 29]:

$X=[(M 1+2 m 1)+(M 2-2 m 2)] / 2$,

where $X$ is the boundary level of the galectin-3; M1 - the average value of level of the galectin-3 in the group with the absence of the sign (conditionally healthy); $\mathrm{m} 1$ - the standard deviation M1; M2 - the average value of the level of galectin3 in the group with the presence of a sign (conditionally ill); $\mathrm{m} 2$ - M2 the standard deviation.

All patients were prescribed baseline therapy in accordance with the recommendations of the Ukrainian Association of Cardiologists (2014) regarding the prevention and treatment of arterial hypertension, the unified clinical protocol for medical treatment for arterial hypertension, approved by the Order of the Ministry of Health of Ukraine dated May 24, 2012 No. 384 and clinical guidelines for arterial hypertension of the European Society of Hypertension (ESH) and the European Society of Cardiology (ESC) 2013. The research was conducted with the stabilization of patients. Subsequently, a dynamic observation of patients prescribed antihypertensive (in the case of CHF and, if necessary, symptomatic) therapy for 6 months.

To evaluate the treatment efficacy, clinical criteria were developed for which the changes in the concentration of the biomarker of galectin-3 were considered. In the first stage, 2 graduations of patients were selected: the first - persons with a good effect of treatment in which the target blood pressure level $\leq 140 / 90 \mathrm{~mm} \mathrm{Hg}$ was reached and a decrease of 1 functional class for NYHA in the presence of CHF. The second (moderate effect) patients whose arterial pressure decreased by $10 \%$ and more but the target pressure was not achieved and the decrease in CHF patients in the functional class I and more.

Statistical analysis included calculation of primary statistics, detection of differences between groups by statistical characteristics, determining the relationship between variables using parametric (Pearson correlation) and nonparametric (Spearman correlation) analysis. For quantitative indicators, the primary statistical processing included the calculation of the arithmetic mean $(M)$, the standard deviation $(\mathrm{m})$, the mean-square deviation $(\sigma)$. The differences between the samples, distributed according to the law of normal distribution, were evaluated for Student's t-criterion (t) for unrelated measurements. Using a regression analysis, a mathematical model of the effect on the galectin3 studied factors in patients with HD was determined. R2 is a determination coefficient whose value is from 0 to 1 and the closer the value to 1 is the stronger the connection. $F$ - Fischer's criterion is a parametric criterion and is used to compare the variances of the two variation series. The regression equation has the following form: $Y=a+b \times X$, where $y$ - is a dependent variable, $x$ - is an independent variable, $a-$ is a free member, and $b-$ is a regression coefficient.

Mathematical processing was performed on a personal computer using standard statistical package "Statistica 10.0".

For initial preparation of tables and intermediate calculations Microsoft Excel package was used.

\section{Results}

The use of biological markers that reflect different aspects of the pathogenesis of $\mathrm{CHF}$ should be considered as a priority area in identifying patients at high risk of adverse clinical states, as well as for biomarker-controlled therapy and monitoring the feasibility of the therapy.

It was interesting to determine what affects the level of galectin-3. Using a method of stepwise multiple regression with the inclusion of predictors, the analysis developed a mathematical model for the effect on the concentration of galectin-3 in plasma blood factors in patients with HD II. In the uncomplicated course of the disease, the equation has the form:

$\mathrm{y}_{1}=2.486+0.100 \times \mathrm{x}_{3}+0.077 \times \mathrm{x}_{1}+0.080 \times \mathrm{x}_{6}+0.060$ $\times x_{12}\left(R^{2}=78.19 \%, p<0.05, F=2.47\right)$,

where, $\mathrm{y}_{1}$ - level of galectin-3 (index of dependent variable); $x_{1}$ - emission fraction in $\% ; x_{3}$ - shock volume, $\mathrm{ml}$; $\mathrm{x}_{6}$ - systolic blood pressure, $\mathrm{mmHg} ; \mathrm{x}_{12}$ - diastolic arterial pressure, $\mathrm{mm} \mathrm{Hg}$.

And also the model of influence on the concentration of galectin-3 studying factors in patients with HD that complicated the CHF of men:

$\mathrm{y}_{2}=4.250+0.080 \times \mathrm{x}_{1}+0.008 \times \mathrm{x}_{2}-0.090 \times \mathrm{x}_{3}+0.080 \times$ $x_{4}+0.113 \times x_{6}+0.100 \times x_{7}+0.104 \times x_{8}+0.200 \times x_{9}+0.277$ $\times x_{10}-0.230 \times x_{11}\left(R^{2}=82.14 \%, p<0.05, F=14.47\right)$, where, $y_{2}$ - level of galectin-3 (index of dependent variable); $x_{1}$ emission fraction in $\% ; x_{2}$ - is a very low density lipoprotein cholesterol, $\mathrm{mmol} / / ; \mathrm{x}_{3}$ - shock volume, $\mathrm{ml} ; \mathrm{x}_{4}$ - heart rate, bpm; $x_{6}$ - systolic blood pressure, $m m H g . ; x_{7}$ - age, years; $x_{8}$ - is a functional class; $x_{9}$ - index of left ventricular myocardial mass $\mathrm{g} / \mathrm{m}^{2} ; \mathrm{x}_{10}$ - thickness of interventricular septum, $\mathrm{mm}$; $\mathrm{x}_{11}$ - total cholesterol, $\mathrm{mmol} / \mathrm{l}$.

Table 1 shows levels of galectin-3 before and after 6 months of treatment.

According to the findings, a higher level of galectin-3 was observed in patients with HD complicated by $\mathrm{CHF}$ compared to patients with uncomplicated HD. At the same time, the concentration of galectin-3 significantly decreases against the background of treatment. The level of blood in the galectin-3 in patients with HD II stage was close to 
Table 1. Levels of galectin-3 before and after 6 months of treatment in patients with $\mathrm{HD}(\mathrm{M} \pm \sigma)$.

\begin{tabular}{|c|c|c|c|}
\hline Groups & $\begin{array}{c}\text { Plasma level of } \\
\text { galectin-3 before } \\
\text { treatment }(\mathrm{ng} / \mathrm{ml})\end{array}$ & $\begin{array}{c}\text { Plasma level } \\
\text { of galectin-3 } \\
\text { after treatment } \\
(\mathrm{ng} / \mathrm{ml})\end{array}$ & $\mathrm{p}$ \\
\hline $\begin{array}{c}\text { Persons without } \\
\text { cardiovascular } \\
\text { pathology ( } \mathrm{n}=79)\end{array}$ & $\begin{array}{c}7.034 \pm 0.122 \\
(1)\end{array}$ & & \\
\hline $\begin{array}{c}\text { Patients with HD of } \\
\text { stage II ( } \mathrm{n}=62)\end{array}$ & $\begin{array}{c}21.31 \pm 0.22 \\
(2)\end{array}$ & $\begin{array}{c}16,77 \pm 0.38 \\
(4)\end{array}$ & $\mathrm{p}_{4-2}<0.05$ \\
\hline $\begin{array}{c}\text { Patients with HD of } \\
\text { stage III ( } \mathrm{n}=50)\end{array}$ & $\begin{array}{c}46.65 \pm 2.18 \\
(3)\end{array}$ & $\begin{array}{c}24.99 \pm 0.93 \\
(5)\end{array}$ & $\mathrm{p}_{5-3}<0.05$ \\
\hline $\mathrm{P}$ & $\begin{array}{c}\mathrm{p}_{2-1}<0,001 \\
\mathrm{p}_{3-2}<0.001 \\
\mathrm{p}_{3-1}<0.001\end{array}$ & $\mathrm{p}_{5-4}<0.001$ & \\
\hline
\end{tabular}

Notes: (1), (2), (3), (4), (5) - relevant groups; $p$ - the indicator of the corresponding reliable values.

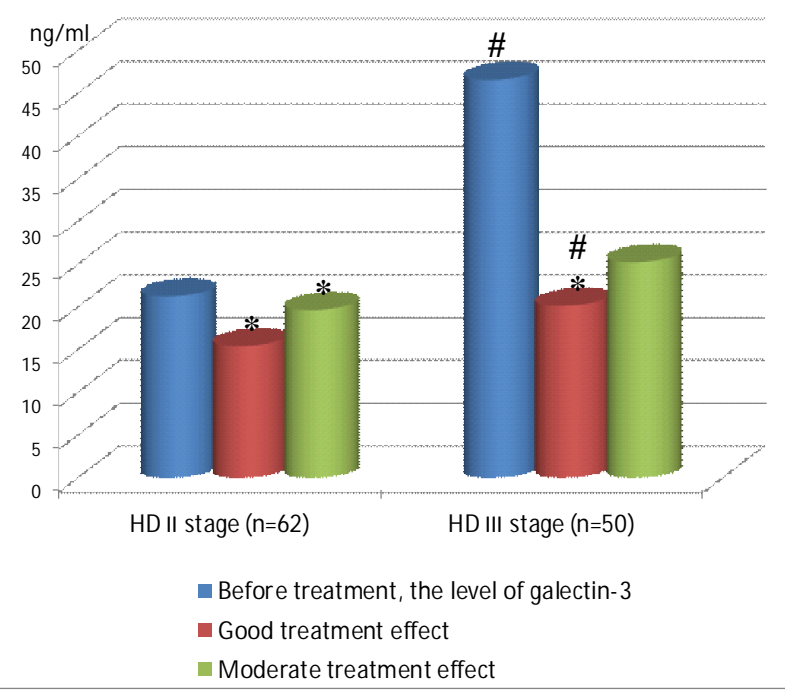

Fig. 1. Levels of galectin-3 in blood plasma after treatment in men with HD II and III stages, depending on the effectiveness of treatment, $\mathrm{ng} / \mathrm{ml}$.

Notes: \# - the difference between the indices is reliable when comparing the levels of galectin-3 in individuals with HD of stage II, * - the difference between the indices is reliable when compared within a group.

normal values, and in patients with HD III stage slightly exceeded it.

Depending on the effectiveness of the therapy, levels of galectin-3 are shown in Figure 1.

The above data became the basis for calculating the boundary level of galectin-3, which could contribute to the prediction of treatment efficacy: the level of galectin-3 ? $46.51 \mathrm{pg} / \mathrm{ml}$ (sensitivity $94.0 \%$, specificity - 84.2\%, errorfiction $-60.7 \%$, false-negative response $-6.0 \%$, falsepositive response $-15.8 \%$ ) suggests a moderate effect on treatment in male patients of patients with $\mathrm{HD}$ and CHF.

Determination of the boundary level of galectin-3 in a patient before treatment will allow to select those who start therapy can not immediately give a good effect and it is better for them to apply more aggressive therapy.

\section{Discussion}

According to the data received by De Boer R. A. et al. [6] galectin-3 showed the highest degree of correlation with the severity of diastolic dysfunction (high $\mathrm{E} / \mathrm{Ea}$ ) compared to other echocardiographic parameters. In the course of clinical trials, it has been found that expression of galectin-3 increases in patients with a lower left ventricular ejection fraction, regardless of the etiology of heart failure. Also in research by De Boer R. A. and et al. [8] it was found that the concentration of galectin3 is a phenotypic trait that reflects the intensity of cardial and vascular remodeling processes and may help to detect disturbances in the contractile and relaxation capacity of the myocardium, such as the left ventricular ejection fraction or peak systolic, early and late diastolic velocity.

In our opinion, the etiological factor imposes an imprint on the expressiveness of the fibrotic processes in the myocardium. In particular, as shown in Table 1 in patients with HD of stage II, that is, in the presence of left ventricular hypertrophy. Even without signs of CHF above and functional class, the level of galectin-3 was higher than that people without cardiovascular disease of the same age. Thus, galectin-3 can mark and present a left ventricular hypertrophy caused by HD.

At the same time, in relation to the dynamics of the level of galectin-3 in plasma, which were obtained in a small number of studies on the background of ongoing therapy, are contradictory. Thus, the ability of galectin- 3 to predict the efficacy of CHF pharmacotherapy was studied in a study of Cardiac Resynchronization in Heart Failure (CARE-HF) to study the level of galectin-3 in plasma when performing resynchronization therapy, and included 250 people who had resynchronized therapy, however, no significant changes in the level of galectin-3 were found [11].

In the Deventer-Alkmaar heart failure study (DEAL-HF), 232 patients with NYHA functional class III-IV CHF were included, correlation between the dynamics of the level of galectin-3 in plasma during 12 months of follow-up (3 and 12 months), dynamics left diastolic volume of the left ventricle and left ventricular remodeling parameters were not noted. However, this again did not take into account again the etiology of $\mathrm{CHF}$ [18]. The controversial data from the Framingham study were surveyed of 3353 individuals (59 years of age, $53 \%$ women), an association between the level of galectin-3 and left ventricular mass was found [13].

V. Y. Tsuleiko et al. [24] showed that the level of galectin3 in patients with $\mathrm{CHF}$ in 6 months. against the background of treatment showed a decrease of 1.5 times in patients with adequately selected therapy and amounted to 29.94 $\mathrm{ng} / \mathrm{ml}$, while patients who did not receive targeted doses of drugs, on the contrary, increased to $34.74 \mathrm{ng} / \mathrm{ml}$.

Thus, the level of galectin-3 in blood plasma, according to several researchers, marks not only $\mathrm{CHF}$ as such, but also can reflect the effectiveness of treatment. According to the results of the study, the level of plasma in the blood of galectin3 can be applied to predict the treatment of patients with $\mathrm{HD}$ and $\mathrm{CHF}$. 


\section{Conclusions}

1. The level of galectin-3 in blood plasma may indicate the presence of left ventricular hypertrophy in patients with HD that can be used to diagnose such myocardial remodeling in the absence of echocardiography.

\section{References}

[1] Antomonov, M. Yu. (2004). Calculation of threshold (critical) levels of existing accounting factors for different types of data obtained in hygienic studies. Hygiene of settlements. 43, 573-579.

[2] Berezin, A. E. (2017). Biomarkers in Heart Failure. J. Blood Lymph., 7(3), 172-179. doi: 10.4172/2165-7831.1000172

[3] Chen, A., Hou, W., Zhang, Y., Chen, Y., \& He, B. (2015). Prognostic value of serum galectin-3 in patients with heart failure: a metaanalysis. Int. J. Cardiol., 1(182), 168-170. doi: 10.1016/ j.ijcard.2014.12.137

[4] Chistic, T. V. (2016). An integrated approach to the treatment of disorders of cerebral circulation. Medicine of emergency, 7 , 66-74.

[5] Daghar, S. (2017). The diagnostic value of the level of galectin3 in patients with hypertrophic cardiomyopathy. Scientific Journal "ScienceRise: Medical Science", 4(12), 13-18. doi: 10.15587/ 2519-4798.2017.99566

[6] De Boer, R. A., Voors, A. A., Muntendam, P., van Gilst, W. H., \& van Veldhuisen, D. J. (2009). Galectin-3: a novel mediator of heart failure development and progression. Eur. J. Heart. Fail., 11, 811-817. doi: 10.1093/eurjhf/hfp097

[7] De Boer, Yu, L. \& van Veldhuisen, D. J. (2010). Galectin-3 in cardiac remodeling and heart failure. Curr. Heart Fail. Rep., 7(1), 1-8. doi: 10.1007/s11897-010-0004-x

[8] De Boer, R. A., Edelmann, F., Cohen-Solaal, A., Mamas, A., Maisel A., \& PieskeB. (2013). Galectin-3 in heart failure with preserved ejection fraction. European Journal of Heart Failure,15, 10951101. doi: 10.1093/eurjhf/hft077

[9] Ertl, G. \& Ruschitzka, F. (2014). The Year in Cardiology 2013: heart failure. Eur. Heart J., 35(7), 470-473. doi: 10.1093/ eurheartj/eht555.

[10] Fedkov, S.V. (2015). European strategy for the diagnosis of ischemic heart disease using non-invasive visualization methods. Radiology, radiation therapy, 1-2, 101-112.

[11] Hrynchyshyn, N., Jourdain, P., Desnos, M., Diebold, B. \& Funck, F. (2013). Galectin-3: a new biomarker for the diagnosis, analysis and prognosis of acute and chronic heart failure. Arch. Cardiovasc. Dis., 106(10), 541-546. doi: 10.1016/ j.acvd.2013.06.054

[12] Ignatenko, G. A., Mukhin, I. V. \& Bashkirtsev, A. V. (2012). Pathological remodeling of left ventricular myocardium in patients with arterial hypertension with concomitant ischemic heart disease. Ecological problems of experimental and clinical medicine, 6, 520-527.

[13] Jennifer, E., Chunyu Liu, Asya Lyass, Paul Courchesne \& Daniel Levy. (2012). Galectin-3, a Marker of Cardiac Fibrosis, Predicts Incident Heart Failure in the Community. J. Am. Coll. Cardiol., 60(14), 1249-1256. doi: 10.1016/j.jacc.2012.04.053

[14] Karatolios, K., Chatzis, G., Holzendorf, V., Stork, S, Richter, A...Pankuweit, S. (2018). Galectin-3 as a predictor of left ventricular reverse remodeling in recent-onset dilated cardiomyopathy. Desease markers, 1-7. doi: 10.1155/2018/ 2958219

[15] Kovalenko, V. M., Kornatsky, V. M., Dorogoy, A. P. \& Sirenko, Yu. M. (2014). Diseases of the circulatory system as a medical and social and socio-political problem. Kiev: National Academy
2. The biomarker galectin-3 can be used to effectively predict the efficacy of treatment both in asymptomatic HD and in the development of CHF in its background.

of Medical Sciences of Ukraine, State Institution "National Science Center" Institute of Cardiology. M. D. Strazhesko".

[16] Kovalenko, V. M., Kornatsky, V. M. \& Manoilenko, T. S. (2016). Problems of health and medical care and the model of improvement in modern conditions. Kiev: National Academy of Medical Sciences of Ukraine, State Institution "National Science Center" Institute of Cardiology. M. D. Strazhesko".

[17] Kubanek, M., Sramko, M., Maluskova, J., Kautznerova, D. \& Kautzner, J. (2013). Novel predictors of left ventricular reverse remodeling in individuals with recent-onset dilated cardiomyopathy. J. Am. Coll. Cardiol., 61(1), 54-63. doi: 10.1016/ j.jacc.2012.07.072.

[18] Lok, D. J., Van Der Meer, P., de la Porte, P. W., Lipsic, E., Van Wijngaarden, J., Hillege, H. L., \& van Veldhuisen, D. J. (2010). Prognostic value of galectin-3, a novel marker of fibrosis, in patients with chronic heart failure: data from the DEAL-HF study. Clin. Res. Cardiol., 99(5), 323-328. doi: 10.1007/s00392-0100125-y.

[19] Lupu, A., Lupu, S., \& Agoston-Coldea, L. (2018). Is galectin-3 a promoter of ventricular dysfunction? Revista Romana de Medicina de Laborator, 26(1), 21-36. doi: 10.2478/rrlm-20180001

[20] McMurray, J. J., Adamopoulos, S., Anker, S. D., Auricchio, A., B?hm, M., Dickstein, K., ... ESC Committee for Practice Guidelines. (2012). ESC Guidelines for the diagnosis and treatment of acute and chronic heart failure 2012: The Task Force for the Diagnosis and Treatment of Acute and Chronic Heart Failure 2012 of the European Society of Cardiology. Developed in collaboration with the Heart Failure Association (HFA) of the ESC. Eur. Heart. J., 33(14), 1787-1847. doi: 10.1093/eurheartj/ehs 104

[21] Mikitey, O. N. (2015). Features of development of risk factors in patients with recurrent ischemic stroke. Eastern European neurological journal, 2, 27-30.

[22] Ponikowski, P., Voors, A. A., Anker, S. D., Ruschitzka, F., Rutten, F. H., van der Meer, P., ... ESC Scientific Document Group (2016). 2016 ESC Guidelines for the diagnosis and treatment of acute and chronic heart failure. European Heart Journal, 128, 1-85. doi: 10.1093/eurhearti/ehw128

[23] Radchenko, G. D., \& Sirenko, Yu. M. (2010). Left ventricular hypertrophy: definition, evaluation methods, regression possibilities. Arterial hypertension. 4(12), 1-10.

[24] Tseluyko, V. Y., Matviychuk, N. V. \& Kinoshenko, K. Yu. (2014). Galectin-3 in patients with chronic heart failure. Ukrainian Cardiology Magazine, 3, 77-81.

[25] Tseluyko, V. Y., Yakovleva, L. M. \& Matuzok, O. E. (2017). Clinical and anamnestic characteristics and indicators of intracardiac hemodynamics in patients with acute myocardial infarction depending on the polymorphism of $\mathrm{T}(-786 \mathrm{C})$ endothelial $\mathrm{NO}$ synthase gene. Heart and blood vessels, 2, 46-52.

[26] Van Vark, L. C., Lesman-Leegte, I., Baart, S. J., Postmus, D., Pinto, Y. M., de Boer, R.A., ... TRIUMPH (Translational Initiative on Unique and Novel Strategies for Management of Patients with Heart Failure) Investigators (2017). Prognostic Value of Serial Galectin-3 Measurements in Patients With Acute Heart Failure. J. Am. Heart Assoc., 6(12), 1-12. doi: 10.1161/ 
JAHA.116.003700

[27] Wermelt, J. A. \& Schunkert, H. (2017). Management of arterial hypertension. Herz, 42(5), 515-526. doi: 10.1007/s00059-0174574-1

[28] Wu, C. K., Su, M. Y., Lee, J. K., Chiang, F. T., Hwang, J-J., Lin, J.L., ... Tsai, C. T. (2015). Galectin-3 level and the severity of cardiac diastolic dysfunction using cellular and animal models and clinical indices. Sci. Rep., 5, 17007. doi: 10.1038/srep17007
[29] Zhebel, V. M., Sakovich, O. O., Vilchinsky, G. V., \& Singkh, O. O. (2012). Method of diagnosis of chronic heart failure in postmenopausal women with hypertension. Pat. 67486 УкраїHa, Ukraine. MPK G01N 33/48 (2006.01).

[30] Zhong, X., Qian, X., Chen, G., \& Song, X. (2018). The role of galectin-3 in heart failure and cardiovascular disease. Clinical and Experimental Pharmacology and Physiology, 46 (3), 197203. doi: $10.1111 / 1440-1681.13048$

\section{ГАЛЕКТИН-3 - СУЧАСНИЙ БІОМАРКЕР ДІАГНОСТИКИ ГІПЕРТРОФІЇ ЛІВОГО ШЛУНОЧКА ТА ХРОНІЧНОЇ СЕРЦЕВОЇ НЕДОСТАТНОСТІ І КОНТРОЛЮ ЛІКУВАННЯ ХВОРИХ НА ГІПЕРТОНІЧНУ ХВОРОБУ}

\section{Ружанська В.О., Сивак В.Г., Поліщук Т.В., Жебель В.М.}

Розробка нових методів профрілактики та лікування хронічної серцевої недостатності та контролю його ефрективності являє собою актуальну медико-соціальну проблему. В цьому відношенні великий інтерес представляє застосування нових біологічних маркерів даного захворювання, котрі можуть бути корисними для ранньої діагностики захворювання, прогнозу щодо його клінічного перебігу, моніторування наслідків фрармакотерапії (персоніфрікована медицина) та відігравати важливу роль у стратифрікації ризику пацієнта. За рекомендацією Американської асоціації серия з профрілактики та лікування хронічної серцевої недостатності, 2013 рік в пул таких біомаркерів введено галектин-3. Мета роботи: покращити прогнозування перебігу та ефрективності терапії гіпертонічної хвороби та хронічної серцевої недостатності яка є ї ускладненням у чоловіків 40-60 років шляхом визначення рівня галектину-3 в якості біомаркера. У зазначеного контингенту обстежених вивчали концентрацію галектину-3, показники центральної та системної гемодинаміки в осіб без серцево-судинної патології $(n=79)$, чоловіків хворих на гіпертонічну хворобу з гіпертрофрією міокарда $(n=62)$ та з хронічною серцевою недостатністю II-III функціонального класу по NYHA (n=50). Рівень галектину-3 визначався за допомогою імуноферментного аналізу на апараті "Stat Fact 300". Структурно-фрункціональні показники міокарда оцінювали за допомогою ультразвукового дослідження на апараті "RADMIR ULTIMARA". Отримані дані обробляли математично на персональному комп'ютері з використанням стандартного статистичного пакету "Statistica 10.0". Усі дані представлені у вигляді середнього значення (M) та стандартного відхилення ( $\pm \sigma)$. Встановлено, що концентрація галектину-3 достовірно знижується на фроні проведеного лікування. Рівень в крові галектину-3 у хворих на гіпертонічну хворобу II стадії при доброму ефекті лікування наблизився до нормальних величин порівняно з особами з помірним ефектом від лікування, а у пацієнтів з діпертонічною хворобою III стадіі відповідно теж став меншим, що свідчить про можливість моніторингу терапії з використанням даного біомаркера. Також визначено математичну модель впливу на галектин-3 досліджуваних факторів у хворих на гіпертонічну хворобу. Розраховано межовий рівень галектину-3 - 46,51 па/мл, що дозволяє передбачити помірний ефект від лікування у осіб чоловічої статі, хворих на гіпертонічну хворобу та хронічну серцеву недостатність.

Ключові слова: гіпертонічна хвороба, гіпертрофрія лівого шлуночка, хронічна серцева недостатність, галектин-3.

ГАЛЕКТИН-3 - СОВРЕМЕННЫЙ БИОМАРКЕР ДИАГНОСТИКИ ГИПЕРТРОФИИ ЛЕВОГО ЖЕЛУДОЧКА И ХРОНИЧЕСКОЙ СЕРДЕЧНОЙ НЕДОСТАТОЧНОСТИ И КОНТРОЛЯ ЛЕЧЕНИЯ БОЛЬНЫХ С ГИПЕРТОНИЧЕСКОЙ БОЛЕЗНЬЮ

Ружанская В.А., Сивак В.Г., Полищук Т.В, Жебель В.Н.

Разработка новых методов профилактики и лечения хронической сердечной недостаточности, а также контроля его эфффективности представляет собой актуальную медико-социальную проблему. В этом отношении большой интерес представляет применение новых биологических маркеров данного заболевания, которые могут быть полезными для ранней диагностики заболевания, прогноза относительно его клинического течения, мониторинга последствий фрармакотерапии (персонифицированная медицина) и играть важную роль в стратифиикации риска пациента. Согласно рекомендации Американской ассоциации сердиа по профрилактике и лечению хронической сердечной недостаточности 2013 год, в пул таких биомаркеров введено галектин-3. Цель работы: улучшить прогнозирование течения и эфрфрективности терапии гипертонической болезни и хронической сердечной недостаточности, которая является ее осложнением у мужчин 40-60 лет путем определения уровня галектина-3 в качестве биомаркера. У данного контингента обследованных изучали концентрацию галектина-3, показатели центральной и системной гемодинамики у лиц без сердечно-сосудистой патологии $(n=79)$, мужчин больных гипертонической болезнью с гипертрофией миокарда $(n=62)$ и с хронической сердечной недостаточностью II-III функционального класса по NYHA $(n=50)$. Уровень галектина-3 определялся с помощью иммуноферментного анализа на аппарате "Stat Fact 300". Структурно-функциональные показатели миокарда оценивали с помощью ультразвукового исследования на аппарате "RADMIR ULTIMARA". Полученные данные обрабатывали математически на персональном компьютере с использованием стандартного статистического пакета "Statistica 10.0". Все данные представлены в виде среднего значения (M) и стандартного отклонения ( $\pm \sigma)$. Установлено, что концентрация галектина-3 достоверно снижается на фроне проводимого лечения. Уровень галектина-3 в плазме крови у больных гипертонической болезнью II стадии при хорошем эффректе лечения приблизился к нормальным величинам по сравнению $c$ лицами с умеренным эффректом от лечения, а у пациентов с гипертонической болезнью III стадии соответственно тоже стал меньше, что свидетельствует о возможности мониторинга терапии с использованием данного биомаркера. Также определена математическая модель влияния на галектин-3 изучаемых факторов у больных гипертонической болезнью. Рассчитан предельный уровень галектина-3 - 46,51 па/мл, что позволяет предположить умеренный эфффект от лечения у лиц мужского пола больных гипертонической болезнью и хронической сердечной недостаточностью.

Ключевые слова: гипертоническая болезнь, гипертрофия левого желудочка, хроническая сердечная недостаточность, галектин-3. 